\title{
PENYULUHAN PENTINGNYA LEGALISASI PERKAWINAN
}

\author{
Setiawati \\ aProgram Studi Pendidikan Pancasila dan Kewarganegaraan, Fakultas Keguruan dan Ilmu Pendidikan, \\ Universitas Pamulang* \\ tya.unpam@gmail.com \\ *korespondensi penulis \\ Naskah diterima: 26 Februari 2019, direvisi: 5 Maret 2019, disetujui: 26 Maret 2019
}

\begin{abstract}
Abstrak
Perkawinan adalah ikatan lahir batin antara seorang laki-laki dan perempuan sebagai suami istri dengan tujuan membentuk keluarga atau rumah tangga yang sakinah bahagia dan kekal berdasarkan Ketuhanan Yang Maha Esa. Sebuah perkawinan yang dilakukan tanpa dilakukannya pencatatan maka perkawianan tersebut tidak memiliki kekuatan hukum yang tetap. Faktanya praktik di masyarakat, apalagi didaerah-daerah terpencil, proses pencatatan pernikahan dalam dokumen negara sangat jarang diperhatikan. Hal ini disebabkan karena kurangnya pengetahuan sebagian masyarakat desa tegal terhadap peraturan perundang-undangan tentang perkawinan, baik dari aspek hukum Islam maupun aspek hukum positif. Oleh karena itu dipandang perlu untuk dilakukan penyuluhan terkait permasalahan tersebut. Tujuan dilakukannya pengabdian ini untuk memnberikan pemahaman kepada masyarakat Kp. Sasak terkait pentingnya legalisasi perkawinan. Metode yang digunakan dalam pengabdian ini dilakukan dengan cara memberikan penyuluhan. Dari hasil survey dan wawancara yang dilakukan sebelum penyuluhan banyak warga masyarakat yang belum paham terkait pentingnya mencatatkan perkawinan yang telah dilaksanakan dan apa saja akibat yang ditimbulkan karena perkawinan tidak di legalisasi. Adanya penyuluhan ini disambut baik oleh masyarakat, mereka sangat antusias mengikuti kegiatan ini. Setelah diadakannya penyuluhan ini banyak perkembangan yang terjadi, masyarakat mulai banyak yang melakukan kepengurusan dokumen untuk melegalkan perkawinan mereka yang sebelumnya dilakukan secara siri.
\end{abstract}

Kata kunci: Perkawinan, Legalisasi, Hukum

\section{Abstract}

Marriage is a bond born of inner between a man and woman as husband and wife with the aim of forming a family or household that sakinah happy and remain upon the divinity of the one true God. The recording of the marriage arranged for without recording, a marriage does not have the force of law. In fact the practice in public, let alone the remote logging process didaerah-daerah wedding in the document state is rarely noticed. This is because of the lack of knowledge most villagers tegal against legislation on marriage, both from the aspect of Islamic law as well as the positive aspects of the law. It is therefore deemed necessary to do the problems associated outreach. The purpose of doing this devotion to understanding memnberikan to the community related to the importance of the Kp Sasak. legalization of marriage. The methods used in the consecration is done by giving the extension. From the results of the survey and interviews conducted before the extension is still a lot of the public who do not know how important the legalization of marriage and what are the consequences arising because of the marriage not in legalization. The existence of this extension was well received by the public, they are very enthusiastic to follow this activity. After holding this extension a lot of development going on, many communities do governance documents to legalize their marriage that was previously done in the series.

Keywords: marriage, Legalization, legal 


\section{PENDAHULUAN}

Perkawinan adalah ikatan lahir batin antara seorang laki-laki dan seorang perempuan sebagai suami istri dengan tujuan membentuk keluarga atau rumah tangga yang sakinnah bahagia dan kekal berdasarkan Ketuhanan Yang Maha Esa. Dengan demikian, pernikahan adalah suatu akad yang secara keseluruhan aspeknya dikandung dalam kata nikah atau tazwīj dan merupakan ucapan seremonial yang sakral.

Perkawinan yang dibina antara pria dan wanita bukan orientasi kepada kebutuhan biologis, namun perkawinan dianggap suatu hal yang sakral sebagai kodrat hidup manusia yang saling berpasang-pasangan. Dalam ajaran Islam perkawinan sebagai bentuk ketaqwaan kepada Allah SWT. Perkawinan mencangkup unsur-unsur pokok diantaranya kehidupan lahir batin, unsur kemanusiaan, kerohanian, jasmaniah, dan unsur kebenaran. Sebelum seseorang melaksanakan perkawinan maka seyogyanya memiliki 3 pedoman, yaitu: Iman, Islam dan Ikhlas.

Pada dasarnya setiap perkawinan yang sah bagi seorang muslim adalah jika perkawinan dilakukan sesuai aturan agama Islam dan dicatat dalam dokumen pencatatan perkawinan yang ada di Kantor Urusan Agama. Sesuai dengan ketentuan pasal 2 ayat (1) dan ayat (2) Undang-undang Nomor 1 tahun 1974 tentang Perkawinan, yaitu :

$$
\begin{aligned}
& \text { Ayat (1) Perkawinan adalah sah } \\
& \text { apabila dilakukan menurut } \\
& \text { hukum masing-masing agama } \\
& \text { dan kepercayaannya itu. }
\end{aligned}
$$
Ayat (2) Tiap-tiap perkawinan dicatat menurut peraturan perundang-undangan yang berlaku.

Berdasarkan ketentuan diatas, maka definisi "SAH" dalam perkawinan mengandung dua makna. Pertama, ikatan perkawinan dapat disebut sah secara agama jika dilakukan sesuai dengan hukum agama masing-masing. Kedua, perkawinan dianggap sah secara hukum negara bila pernikahan tersebut dicatatkan pada Kantor Urusan Agama (khusus pasangan muslim) dan di kantor catatan sipil (bagi pasangan non muslim).

Pada mulanya dalam syariat Islam, baik yang termaktub dalam kitab suci maupun hadits terkait pencatatan perkawinan tidaklah diatur secara gamblang, tetapi hukum islam di Indonesia mengatur tentang pencatatan perkawinan dengan berbagai alasan dan pertimbangan manfaat dan maslahat bagi pihak pihak yang melaksanakan perkawinan. 
Sebuah perkawinan yang dilaksanakan wajib dicatatkan agar dapat memberikan kenyamanan kepada masyarakat serta mewujudakan ketertiban dan keteraturan.

Untuk mencapai tujuan tersebut maka pencatatan perkawinan diatur dalam perundang-undangan agar martabat dan kesucian dari sebuah perkawinan tetap terjaga. Perkawinan yang dicatatkan dibuktikan dengan adanya kepemilikan Akta Nikah yang dipegang oleh masing masing pasangan baik suami maupun isteri.

Kepemilikan Akta Nikah dipegang oleh masing-masing pasangan guna untuk menghindari terjadinya perselisihan diantara kedua pasangan jika salah satu diantara mereka tidak bertanggung jawab sehingga salah satunya dapat melakukan upaya hukum agar dapat memperolah dan mempertahankan haknya masing-masing.

Pasangan yang telah melangsungkan perkawinan diberikan akta nikah yang menjadi bukti nyata terhadap tindakan (perbuatan hukum) yang telah dilakukan.

Dalam KHI pasal 5 dijelaskan mengenai perkawianan yang telah dicatatkan yang menjelaskan bahwa:

"Agar terjamin ketertiban perkawinan bagi masyarakat Islam setiap perkawinan harus dicatat. Pencatatan perkawinan tersebut pada ayat (1) dilakukan oleh Pegawai Pencatat Nikah sebagaimana diatur dalam Undang-Undang Nomor 22 Tahun 1946 jo UndangUndang Nomor 32 Tahun 1954".

Adapun secara teknis untuk melaksanakan pencatatan perkawinan diatur dalam kompilasi hukum islam pasal 6 yang bunyinya

"Untuk memenuhi ketentuan dalam Pasal 5, setiap perkawinan harus dilangsungkan di hadapan dan di bawah pengawasan Pegawai Pencatat Nikah. Perkawinan yang dilakukan di luar pengawasasn Pegawai Pencatat Nikah tidak mempunyai kekuatan hukum".

Aturan-aturan perundang-undangan yang dibuat terkait pengaturan untuk mencatatkan perkawinan merupakan syarat administratif yang harus dipenuhi. Sebuah perkawinan dikatakan sah apabila memenuhi standar sah berdasarkan ketentuan yang berlaku dan berdasar atas norma-norma agama dari masing-masing pihak yang melangsungkan perkawinan.

Sebuah perkawinan wajib dicatatkan karena tanpa dilakukannya pencatatan, perkawinan yang telah dilaksanakan tidak mempunyai kekuatan hukum dan dapat menimbulkan kerugian terutama untuk isteri dan anak hasil perkawinan tersebut.

Contoh kerugian yang dapat ditimbulkan karena perkawinan tidak dicatatkan ialah, 
apabila ada salah satu pihak yang lalai atau tidak betanggung jawab, maka pihak lain tidak dapat melakukan upaya hukum karena tidak adanya bukti-bukti otentik yang dimiliki secara legal dari perkawinan yang telah dilaksanakan. Kondisi tersebut tentu sangat bertentangan dengan visi dan misi dari sebuah perkwinan itu sendiri.

Namun faktanya praktik di masyarakat, apalagi di daerah-daerah terpencil, proses pencatatan pernikahan dalam dokumen negara sangat jarang diperhatikan. Ada beberapa faktor yang menyebabkan sebagian msyarakat tidak mencatatkan pernikahannya di instansi pemerintah (KUA). Faktor pertama sebagian besar masyarakat beranggapan bahwa nikah secara hukum agama saja sudah cukup dalam melegalkan hubungan antara dua pasangan dan tidak perlu dicatatkan dalam buku nikah. Faktor yang kedua karena tidak memiliki biaya untuk administrasi pencatatan pernikahan. Faktor lain adalah karena takut diketahui bahwa dirinya telah melanggar aturan, contohnya salah satu aturan yang diterapkan yang melarang pegawai negeri menikah lebih dari satu.

Sebagai bagian dari warga negara Indonesia yang harus taat dan patuh terhadap peraturan perundang-undangan tentang perkawinan, pemerintah desa tegal kecamatan kemang juga dihadapkan pada kenyataan bahwa sebagian masyarakatnya enggan untuk mencatatkan pernikahannya. Hal ini disebabkan karena kurangnya pengetahuan sebagian masyarakat desa Tegal terhadap peraturan perundang-undangan tentang perkawinan, baik dari aspek hukum Islam maupun aspek hukum positif.

Berdasarkan penelitian yang sebelumnya pernah dilakukan oleh Susanto dismpulkan bahwa "masyarakat cenderung enggan mencatatkan perkawinannya karena keterbatasan pengetahuan dan ekonomi”.

Terkait temuan-temuan permasalah yang ada tersebut, oleh karenanya dipandang perlu untuk dilakukan penyuluhan terkait permasalahan tersebut.

Oleh karena itu untuk memberikan solusi terkait permasalahan tersebut, tim dosen Universitas Pamulang khususnya dosen Program Studi Pendidikan Pancasila dan Kewarganegaraan Fakultas Keguruan dan Ilmu Pendidikan bekerjasama dengan pimpinan Majelis Ta'lim Daarul ulum Kp. Sasak Desa Tegal Kecamatan Kemang Kabupaten Bogor untuk mengadakan penyuluhan hukum terkait pentingya legalisasi perkawinan agar masyarakat di Kampung sasak lebih paham terkait legalisasi perkawinan.

Adapun tujuan diadakannya pengabdian masyarakat ini adalah untuk memberikan 
pengetahuan dan pemahaman kepada masyarakat Kampung sasak terutama kaum perempuan agar tidak ada lagi yang menjadi korban pernikahan sirri. Karena selain merugikan perempuan itu sendiri nikah sirri juga menimbulkan dampak negatif terhadap status anak hasil perkawinan siri tersebut.

Tujuan lain diadakannya kegiatan ini untuk memberikan kesempatan kepada dosen Fakultas Keguruan dan ilmu Pendidikan untuk melaksanakan salah satu tugas kewajiban yaitu pengabdian kepada masyarakat. Kegiatan ini menjadi salah satu kontribusi nyata yang dapat dilakukan oleh dosen sekaligus memperkenalkan lebih luas lagi tentang Universitas Pamulang kepada masyarakat di lingkungan Kabupaten Bogor.

Selain daripada tujuan-tujuan yang dimaksudkan kegiatan ini diharapkan dapat memberikan manfaat kepada masyarakat wilayah Kampung Sasak terkait pemahaman terhadap Undang Undang No.1 tahun 1974 tentang perkawinan.

\section{METODE}

Metode yang digunakan dalam pengabdian masyarakat di Kp. Sasak RT.05/08 Kecamatan Kemang Kabupaten Bogor ini yaitu dengan metode penyuluhan kepada masyarakat. Namun sebelum kegiatan penyuluhan ini dilaksanakan terlebih dahulu dilakukan survey dan wawancara kepada masyarakat sekitar terkait permasalahan yang ada sebagai dasar utama untuk dilaksanakannya kegiatan penyuluhan ini.

Target sasaran kegiatan ini adalah Masyarakat Kampung Sasak Desa Tegal Kecamatan Kemang Kabupaten Bogor, terutama ibu-ibu Majlis Ta'lim Daarul ulum

Pelaksanaan penyuluhan dilakukan dengan diawali pemberian pemahaman materi terkait hukum perkawinan di Indonesia, perkawinan siri hukum dan dampaknya serta Pentingnya legalisasi perkawinan. Materi ini disampaikan oleh salah satu dosen Fakultas Keguruan dan Ilmu Pendidikan yaitu Bapak Fery Kurniawan, SH.,MH., yang juga didukung oleh beberapa dosen lainnya diantaranya R. Dede Siswandi, S.Sos,M.Pd., Aep Saifullah, S.Ag.,M.Pd.I, Drs. Samino,MA.ED., Drs. Abdul Kohar, M.Pd., Yulita Pujilestari, S.H., M.H., Arif Hidayat, SH.,MH., Endang Prastini, S.Pd.,MH., Ichwani Siti Utami, S.Pd.,MH.

Kegiatan ini juga terlaksana berkat kerjasama dengan pimpinan Majelis Ta'lim Daarul Ulum yaitu Ibu Ustajah Satimah, S.Pd.I yang bersedia menyediakan tempat dan fasilitas serta menginformasikan kepada jamaahnya untuk mengikuti kegiatan ini.

\section{HASIL DAN PEMBAHASAN}


Kegiatan pengabdian kepada masyarakat yang dilaksanakan di Majlis Ta'lim Daarul Ulum berjalan sesuai dengan rencana, kegiatan ini dilaksanakan dari tanggal 2 sampai 4 November 2018. Pada tahap perencanaan tim dosen pengabdi melakukan observasi kepada ibu-ibu di lingkungan Kampung Sasak, pada tahap observasi ini dilakukan wawancara kepada beberapa orang sehingga ditemukan permasalahan yang banyak terjadi di lingkungan masyarakat terkait pernikahan sirri yang dijadikan dasar untuk diadakannya kegiatan pengabdian ini.

Hasil wawancara dengan salah satu nara sumber disimpulkan bahwa "masih banyak warga masyarakat yang menikah tanpa melegalkan pernikahannya atau tanpa melakukan pencatatan di Kantor Urusan Agama setempat karena ketidaktahuannya terkait hukum perkawinan tersebut di mata hukum serta dampak apa saja yang ditimbulkan dari perkawinan tersebut dan belum ada kegiatan penyuluhan terkait pentingnya legalisasi perkawinan serta kaitannya dengan Undang-Undang No.1 tahun 1974 tentang perkawinan”. (wawancara dengan Ibu Mumun 2 November 2018).

Dalam waktu yang berbeda dilakukan pula wawancara dengan nara sumber lainnya, kesimpulan wawancara tersebut bahwa" banyaknya perempuan yang mau melakukan perkawinan sirri karena keterbatasan biaya". (wawancara ibu Sarminah 2 November 2018)

Hasil dari wawancara tersebut menjadi landasan utama tim dosen pengabdi mengadakan kegiatan pengabdian masyarakat dengan memberikan penyuluhan terkait pentingnya legalisasi perkawinan.

Pada tahap perencanaan dilakukan pembentukan tim dosen untuk melakukan pengabdian kepada masyarakat, perencanaan waktu dan tempat pengabdian serta mengurus izin pengabdian baik kepada Universitas Pamulang maupun perizinan ke tempat pengabdian di Majelis Ta'lim Daarul Ulum. Kegiatan selanjutnya Tim pengabdian memberikan sosialisasi tentang penyuluhankepada masyarakat sekitar dan mengundang ketua Majlis Ta'lim beserta dewan pengajar lainnya untuk memberitahukan terkait diadakannya kegiatan penyuluhan kepada ibu-ibu Majlis Ta'lim Daarul Ulum.

Pada tahap pelaksanaan kegiatan pengabdian berjalan lancar peserta pengabdian mengikuti kegiatan dari awal sampai akhir acara dengan sangat antusias.

Kegiatan pengabdian ini diawali dengan sambutan dari Dekan program Studi Pendidikan Pancasila dan Kewarganegaran. 
Adapun rincian kegiatan pengabdian masyarakat di Majlis Ta'lim Daarul Ulum

Kampung Sasak Desa Tegal Kecamatan Kemang adalah sebagai berikut:

\begin{tabular}{|lrr|}
\hline \multicolumn{3}{|c|}{ Tahapan Perencanaan } \\
\hline - Melakukan observasi & tentang \\
permasalahan $\quad$ pengabdian & yang \\
dilakukan oleh Tim dosen pengabdian \\
- Merencanakan waktu dan tempat \\
pengabdian \\
- Mengurus perizinan \\
- Sosialisasi kegiatan penyuluhan \\
\hline
\end{tabular}

\section{Tahapan Pelaksanaan}

- Memberikan pemahaman tentang pentingnya legalisasi perkawinan kepada ibu-ibu Majlis Ta'lim Daarul Ulum

- Menjelaskan hukum perkawinan sebagaimana dimaksud dalam UndangUndang No.1 Tahun 1974 tentang perkawinan

- Diskusi tentang permasalahan dan kendala dalam pengurusan pencatatan perkawinan dan bagaimana prosedur untuk melegalkan sebuah perkawin

\begin{tabular}{|c|}
\hline Tahapan Evaluasi \\
\hline 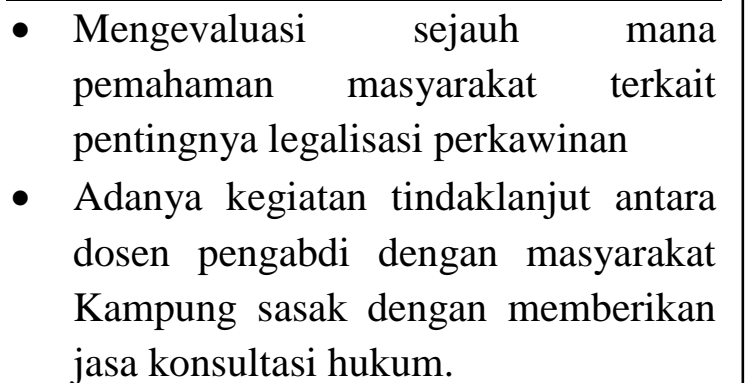 \\
\hline
\end{tabular}

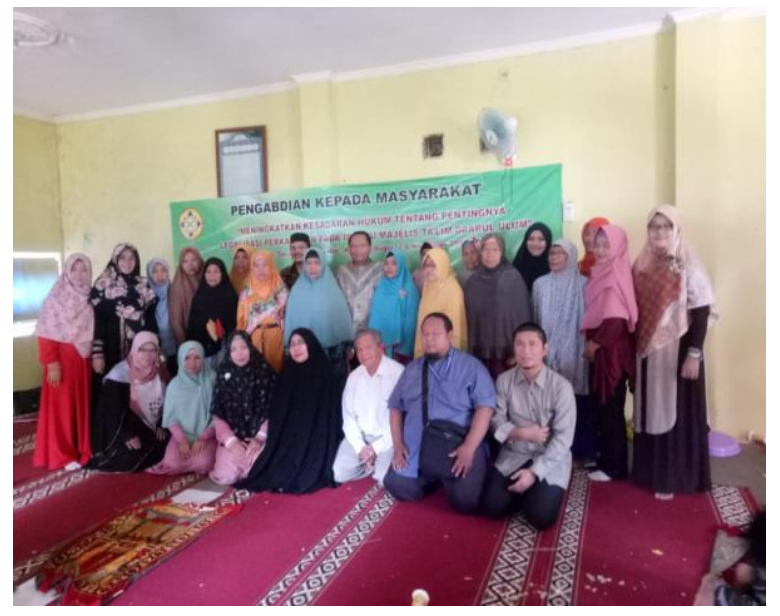

\section{Gambar 1. Dosen Universitas Pamulang} bersama peserta Pengabdian Masyarakat Indikasi tingkat keberhasilan penyuluhan dilihat dari jumlah peserta yang mengikuti kegiatan workshop berjumlah 180 peserta dari total 200 peserta undangan.

Hal ini menandakan bahwa masyarakat di Lingkungan Majlis ta'lim Daarul Ulum ini sangat memerlukan kegiatan penyuluhan ini agar mereka paham dan mengerti apa saja dampak dari sebuah pernikahan siri. 


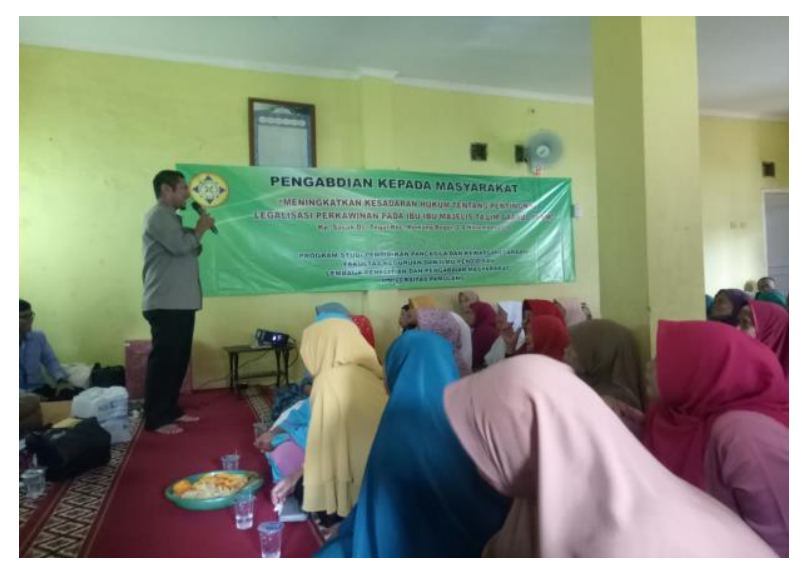

Gambar 2. Penyampaian materi

Penyampaian materi disampaikan oleh narasumber Bapak Fery Kurniawan tentang " Hukum Perkawinan di Indonesia dan Pentingnya Legalisasi Perkawinan”.

Dalam pelaksanaan penyuluhan dijelaskan macam-macam perkawinan, hukum perkawinan di Indonesia, pengertian perkawinan siri beserta dampak yang ditimbulkannya dan juga diberikan penjelasan terkait bagaimana prosedur untuk mencatatkan perkawinan yang sudah dilakukan secara sirri, dan juga terkait pengurusan akta cerai. Karena dalam kegiatan penyuluhan selain banyak yang menanyakan perihal pencatatan sebuah perkawinan juga ditanyakan terkait kepengurusan akta cerai.

Karena masyarakat disini banyak juga yang bercerai begitu saja, dalam arti hanya berdasar pada hukum agama. Apabila sudah tidak diberi nafkah lahir batin kurang lebih selama 3 bulan maka mereka menganggap mereka sudah bercerai, sehingga banyak dari mereka yang melakukan perkawinan kembali tanpa mencatatkan perkawinan disebabkan tidak adanya kepemilikan akta cerai.

Selain itu dalam pelaksanaan penyuluhan ini juga dijelaskan manfaat dari mencatatkan sebuah perkawinan diantaranya perkawinan tersebut mempunyai kekuatan dimata hukum, memudahkan urusan perbuatan hukum lain yang terkait dengan perkawinan, mendapatkan legalitas formal dalam perkawinan serta Sebuah perkawinan yang dicatatkan secara resmi dapat menjamin keamanannya dari kemungkinan terjadinya pemalsuan dan kecurangan lainnya.

Temuan yang ada saat kegiatan penyuluhan bahwa hampir $60 \%$ masyarakat belum mengetahui betapa pentingnya legalisasi sebuah perkawinan serta dampak apa saja yang ditimbulkan akibat dari perkawinan sirri tersebut.

Banyak faktor yang menyebabkan seorang perempuan mau dinikahi secara sirri diantaranya ketidaktahuan masyarakat terkait dampak apa saja yang dapat ditimbulkan jika perkawinan hanya dilakukan secara sirri, faktor ekonomi, untuk menghindarkan diri dari perzinahan karena para orangtua khawatir anak mereka terjerumus ke dalam 
pergaulan bebas yang saat ini sudah semakin melewati batas, dan masih banyak lagi faktor penyebab lainnya.

Setelah dilakukannya penyuluhan terkait pentingnya legalisasi perkawinan $100 \%$ masyarakat menjadi lebih paham betapa pentingnya sebuah legalisasi perkawinan, hal tersebut terbukti dengan banyaknya warga yang datang ke rumah ketua pengabdi untuk menanyakan perihal prosedur yang harus dilakukan jika akan melakukan pencatatan perkawinan yang sebelumnya telah dilakukan secara sirri. Dengan adanya peningkatan pemahaman tersebut membuat masyarakat di lingkungan Kampung Sasak lebih sadar hukum dan tertib administratif.

Dalam sesi diskusi para peserta sangat antusias berpartisipasi aktif dengan menyampaikan beragam pertanyaan terkait hukum perkawinan di Indonesia, dampak perkawinan siri, solusi untuk mencegah terjadinya praktik perkawinan siri dengan kepengurusan legalisasi perkawinan. Pada sesi ini kegiatan diskusi dipandu oleh Setiawati, S.Pd., MH.

Dari berbagai pertanyaan yang ada menitikberatkan bahwa legalisasi perkawinan sangat diperlukan agar kaum wanita dan anak-anak dapat menuntut dan mendapatkan haknya secara layak atau sesuai Undang-Undang yang berlaku.

Penelitian yang dilakukan oleh Susanto (2016), disimpulkan bahwa "perkawinan siri dan dampaknya sangat merugikan bagi kaum perempuan dan anakanak, selain status perkawinan tidak mempunyai kekuatan di mata hukum juga memberikan dampak sosial dan psikologis terhadap kehidupan anak, melemahnya ketahanan keluarga, terhambatnya pemberian waris serta berdampak negatif bagi administrasi kependudukan".

Solusi yang ditawarkan terkait permasalahan tersebut ialah diperlukannya tindak tegas dari Kementerian Agama untuk melakukan serangkaian kegiatan dengan melibatkan para ahli agama untuk mencegah maraknya praktik perkawinan yang dilakukan secara siri yang semakin hari polanya semakin beragam bahkan tidak jarang pada praktiknya bahwa siri dianggap sebagai ajang legalisasi prostitusi.

Oleh karena itu, peran penting lembaga huku dapat menindak para pelaku trafficking dengan kedok pernikahan siri. Disatu sisi pemerintah pusat maupun daerah perlu melakukan berbagai upaya preventif sebelum terjadinya perilaku tersebut dan upaya represif jika terjadi di masyarakat, 
salah satu upaya yang dilakukan dengan cara melakukan pemberdayaan dan perlindungan bagi perempuan dan anak agar tidak menjadi korban pernikahan siri.

Program pendidikan keluarga perlu dilakukan oleh Kementerian pendidikan agar masyarakat yang memang rentan melakukan praktik menikah di usia dini dan perkawinan siri mendapatkan pengetahuan terkait hal tersebut sehingga dapat memproteksi diri mereka.

Selain itu program pencegahan perkawinan dibawah tangan (sirri) yang peduli terhadap masyrakat juga harus dilakukan oleh Kementrian Pemberdayaan perempuan dan perlindungan anak.

KEMENRISTEKDIKTI juga perlu memotivasi Perguruan Tinggi agar mengembangkan program pengabdian kepada masyarakat dengan target atau sasaran utamanya adalah kelompok masyarakat yang beresiko untuk melakukan perkawinan dibawah umur ataupun perkawinan dibawah tangan (sirri), sebagai upaya pencegahan jangka panjang.

\section{KESIMPULAN}

Pelaksanaan kegiatan Pengabdian Kepada Masyarakat oleh Lembaga Penelitian dan Pengabdian Masyarakat (LPPM) Universitas Pamulang yang dilakukan oleh dosen-dosen program studi Pendidikan Pancasila dan Kewarganegaran telah berjalan dengan lancar dan mendapat sambutan baik dari tempat pelaksanan kegiatan penyuluhan ini yaitu Majelis Ta'lim Daarul Ulum Kampung Sasak Desa Tegal Kecamatan Kemang Kabupaten Bogor pimpinan Ibu Ustajah Satimah, S.Pd.I.

Dengan dilaksanakannya Pengabdian Kepada Masyarakat ini diharapkan dapat memberikan pemahaman terkait hukum perkawinan, membuka wawasan masyarakat yang ada di lingkungan Kampung Sasak tentang peraturan perkawinan dan memberikan pengetahuan terkait pentingnya legalisasi perkawinan terhadap ibu- ibu Majelis Ta'lim Daaarul Ulum sehingga tidak ada lagi perempuan-perempuan serta anakanak yang menjadi korban dari perkawinan yang tidak di legalkan.

Karena dampak yang ditimbulkan dari perkawinan siri sangatlah banyak selain perkawinan tersebut tidak mempunyai kekuatan di mata hukum juga memberikan dampak negatif terhadap kehidupan sosial dan psikologis anak, serta menghambat administrasi kependudukan.

Selain itu dengan diadakannya kegiatan ini juga diharapkan dapat diimplementasikan dalam kehidupan masyarakat setempat khusunya sehingga 
menjadi masyarakat yang sadar hukum dan berperilaku sesuai aturan hukum yang berlaku.

\section{UCAPAN TERIMAKASIH}

Suksesnya acara penyuluhan ini tidak terlepas dari peran dan dukungan pihakpihak yang terlibat yang telah memberikan dukungan baik dalam bentuk materil maupun moril.

Terimakasih kepada Yayasan Sasmita Jaya Universitas Pamulang, LPPM Universitas Pamulang, Dekan Fakultas Keguruan dan Ilmu Pendidikan Universitas Pamulang, Ketua Prodi Pendidikan Pendidikan Pancasila dan Kewarganegaraan, Para dosen pengabdi, Mahasiswa yang terlibat dalam pengabdian, ketua Majlis Ta'lim Daarul Ulum beserta jama'ahnya dan semua pihak yang berkontribusi dalam kegiatan pengabdian masyarakat ini.

\section{REFERENSI}

Slamet, Abidin. (1999). Fiqh Munakahat I. Bandung : CV Pustaka Setia.
Muh, Idris Ramulyo. (1996). Hukum

Perkawinan Islam. Jakarta: Bumi

Aksara.

Sulaiman, Rasjid. (2010). Fiqh Islam.

Bandung : Sinar Baru Algensindo

Amir, Syarifuddin. (2009). Hukum

Perkawinan Islam di Indonesia Antara

Fiqh Munakahat dan Undang -

Undang Perkawinan. Jakarta :

Kencana.

Susanto, Aries. 2014. Fenomena Sosial Masyarakat Fasilitator Permudah

Pernikahan Siri. [online].

http://www.koran-o.com/2014/utama-

2/fenomena-sosial-masyarakat-

fasilitator-permudah-pernikahan-siri-

53314, di akses 25 November 2018. 